\title{
Implementasi Pendidikan Karakter di Madrasah
}

\author{
Ani Apiyani \\ IAI Agus Salim Lampung, Indonesia \\ E-mail: ani.apiani87@gmail.com
}

\begin{tabular}{l}
\hline Article Info \\
\hline Article History \\
Received: $2021-12-27$ \\
Revised: $2022-01-22$ \\
Published: $2022-02-03$
\end{tabular}

Published: 2022-02-03

Keywords: Implementation: Madrasah. Character Building;

\begin{abstract}
This study describes the study of the implementation of character education in Madrasahs. The method used in this study uses a library research method or approach, that library research can be interpreted as a series of activities related to the methods of collecting library data, reading and taking notes and processing research materials. The results of this study indicate that in Islam education is not only a process of transferring knowledge from teachers to students. Education in Islam is also accompanied by exemplary efforts (qudwah) from educators in shaping the character of students. Therefore, the effort to give birth to someone who is knowledgeable, has character, is civilized, and has a noble character is part of education. Madrasas as educational institutions must carry out integrated character development into subjects, self-development, and Madrasa culture. Teachers and Madrasas need to integrate the values developed in character education in the existing Curriculum, Syllabus and Learning Program Plans (RPP). The learning principles used in the development of cultural education and national character seek that students recognize and accept the cultural values and character of the nation as their own and are responsible for the decisions they make through the stages of recognizing choices, assessing choices, determining a stance, and then making a decision. value according to self-confidence.
\end{abstract}

\begin{tabular}{l}
\hline Artikel Info \\
\hline Sejarah Artikel \\
Diterima: 2021-12-27 \\
Direvisi: 2022-01-22 \\
Dipublikasi: 2022-02-03
\end{tabular}

Kata kunci: Implementasi; Pendidikan Karakter; Madrasah.

\begin{abstract}
Abstrak
Penelitian ini menjelaskan tentang kajian terhadap implementasi pendidikan karakter di Madrasah. Metode yang digunakan dalam kajian ini menggunakan metode atau pendekatan kepustakaan (library research), bahwa studi pustaka atau kepustakaan dapat diartikan sebagai serangkaian kegiatan yang berkenaan dengan metode pengumpulan data pustaka, membaca dan mencatat serta mengolah bahan penelitian. Hasil penelitian ini menunjukkan bahwa dalam Islam pendidikan tidak hanya proses menstransfer ilmu dari guru kepada murid. Pendidikan dalam Islam juga diiringi dengan upaya keteladanan (qudwah) dari pendidik dalam pembentukan karakter peserta didik. Oleh karena itu, upaya melahirkan seorang yang berilmu, berkarakter, beradab, dan berakhlak mulia adalah bagian dari pendidikan. Madrasah sebagai lembaga pendidikan harus melaksanakan pengembangan karakter terintegrasi ke dalam mata pelajaran, pengembangan diri, dan budaya Madrasah. Guru dan Madrasah perlu mengintegrasikan nilai-nilai yang dikembangkan dalam pendidikan karakter dalam Kurikulum, Silabus dan Rencana Program Pembelajaran (RPP) yang sudah ada. Prinsip pembelajaran yang digunakan dalam pengembangan pendidikan budaya dan karakter bangsa mengusahakan agar peserta didik mengenal dan menerima nilai-nilai budaya dan karakter bangsa sebagai milik mereka dan bertanggung jawab atas keputusan yang diambilnya melalui tahapan mengenal pilihan, menilai pilihan, menentukan pendirian, dan selanjutnya menjadikan suatu nilai sesuai dengan keyakinan diri.
\end{abstract}

\section{PENDAHULUAN}

Manusia merupakan makhluk ciptaan Allah SWT yang paling sempurna memiliki banyak sekali anugerah yang tidak dimiliki oleh makhluk-makhluk lain, hal itu menjadi keistimewaan tersendiri bagi manusia salah satunya adalah akal, yang digunakan manusia sebagai controlling dalam melaksanakan segala tindakan sehingga membentuk karakter yang kuat dalam diri. Karakter merupakan hal yang sangat penting dan mendasar yang membedakan manusia dengan binatang, manusia tanpa karakter adalah manusia yang sudah kehilangan keistimewaannya, karakter yang kuat adalah sandangan fundamental yang memberikan kemampuan kepada populasi manusia untuk hidup bersama dalam kedamaian serta membentuk dunia yang dipenuhi dengan kebaikan dan kebajikan, yang 
bebas dari kekerasan dan tindakan-tindakan tidak bermoral.

Karakter dimaknai sebagai cara berfikir dan berperilaku dari individu untuk hidup dan bekerja sama, dalam lingkup keluarga, masyarakat, bangsa dan Negara (Arifudin, 2020). Individu yang berkarakter baik adalah individu yang dapat membuat keputusan dan siap mempertanggungjawabkan setiap akibat dari keputusannya, karakter dianggap sebagai nilainilai perilaku manusia yang berhubungan dengan Tuhan, diri sendiri, sesame manusia, lingkungan dan kebangsaan yang terwujud dalam pikiran, sikap, perasaan, perkataan dan perbuatan berdasarkan norma-norma agama, hukum, tata krama, budaya, adat istiadat, dan estetika (Hariyanto, 2013), sehingga penguatan pendidikan karakter dalam konteks sekarang menjadi sangat relevan untuk mengatasi dekadensi moral yang sedang terjadi di negara ini, itulah yang menjadikan salah satu instrumen penting yang mempengaruhi maju mundurnya suatu bangsa adalah karakter. Namun saat ini salah satu masalah yang mendapat sorotan dan melahirkan keprihatinan masyarakat saat ini adalah munculnya berbagai bentuk perilaku negatif di kalangan peserta didik kita. Tawuran antar peserta didik, penggunaan narkoba, praktik seks bebas dan sederet contoh perilaku negatif itu merupakan bentuk dari rendahnya karakter peserta didik saat ini.

Perilaku menyimpang dan tidak terpuji yang menerpa para peserta didik sebagaimana disebut di atas merupakan gejala umum yang muncul di berbagai tempat di Indonesia, para orang tua tentu saja khawatir dan cemas terhadap fenomena kemerosotan karakter atau moral di kalangan anak-anak dan remaja itu. Menghadapi fenomena tersebut institusi pendidikan biasanya dipandang sebagai satu alternatif jalan keluar yang cukup mampu mengatasi kemerosotan moral dan perilaku tidak terpuji di kalangan anak dan remaja. Institusi ini memang berfungsi sebagai tempat pembelajaran berbagai ilmu pengetahuan sekaligus pembentuk karakter peserta didik (Supriani, 2022).

Dalam beberapa tahun belakangan, fungsi institusi pendidikan sebagai pembentuk karakter peserta didik dinilai menurun karena ia lebih menitikberatkan fungsinya pada pembelajaran ilmu pengetahuan. Menurut (Qadri, 2003) misalnya memandang bahwa dua faktor dari enam faktor yang menjadi titik lemah sistem pendidikan, yaitu: pertama, pendidikan yang ada tidak berorientasi pada pembentukan kepribadi- an, melainkan lebih berorientasi pada sisi kognitif peserta didik; kedua, anak tidak pernah dididik atau dibiasakan untuk kreatif dan inovatif serta berorientasi pada keinginan untuk tahu.

Pendidikan karakter pada tingkat satuan pendidikan tidak dilaksanakan sebagai mata pelajaran yang berdiri sendiri tetapi diintegrasikan dalam kurikulum dan berfungsi menjadi penguat kurikulum yang sudah ada (Sofyan, 2020), salah satu bentuk implementasi pendidikan karakter sebagai bagian integral dari kurikulum di sekolah dapat dilihat pada kegiatan ekstrakurikuler dan layanan bimbingan konseling, dalam kegiatan ini pendidikan karakter diorientasikan untuk memfasilitasi perkembangan atau perwujudan potensi peserta didik, baik dari aspek pribadi, sosial, belajar, maupun karir. Kegiatan ekstrakurikuler yang selama ini diselenggarakan sekolah dianggap sebagai salah satu media yang potensial untuk pembinaan karakter dan peningkatan mutu akademik peserta didik, melalui kegiatan ekstrakurikuler peserta didik diharapkan dapat mengembangkan kemampuan, tanggung jawab sosial, potensi, dan prestasinya, sementara pelayanan konseling dilaksanakan untuk membantu pengembangan peserta didik sesuai kebutuhan, potensi, bakat, dan minat mereka, hal ini juga dilakukan di Madrasah dalam pem-bentukan karakter peserta didik.

\section{METODE PENELITIAN}

Sesuai dengan karakteristik masalah yang diangkat dalam penelitan ini maka menggunakan Metode Riset kualitatif yaitu menekankan analisanya pada data deskriptif berupa kata-kata tertulis yang diamati, pendekatan kualitatif penulis gunakan untuk menganalisis kajian terhadap implementasi pendidikan karakter di Madrasah, maka dengan sendirinya penganalisaan data ini lebih difokuskan pada Penelitian Kepustakaan (Library Research), yakni dengan membaca, menelaah dan mengkaji bukubuku dan sumber tulisan yang erat kaitannya dengan masalah yang dibahas. Metode yang digunakan dalam kajian ini menggunakan metode atau pendekatan kepustakaan (library research), menurut Zed dalam (Rahayu, 2020) bahwa studi pustaka atau kepustakaan dapat diartikan sebagai serangkaian kegiatan yang berkenaan dengan metode pengumpulan data pustaka, membaca dan mencatat serta mengolah bahan penelitian.

Berdasarkan beberapa definisi penelitian kualitatif di atas dapat disimpulkan bahwa pene- 
litian kualitatif adalah suatu penelitian yang datanya dinyatakan dalam bentuk verbal, tidak menggunakan angka dan analisisnya tanpa menggunakan teknik statistik.

1. Objek Penelitian

Dalam penelitian ini objek penelitian terdiri dari 2 (dua), yaitu objek formal dan objek material (Arifudin, 2018), objek formal dalam penelitian ini berupa data yaitu data yang berhubungan dengan tinjauan kritis kajian terhadap implementasi pendidikan karakter di Madrasah, sedangkan objek materialnya berupa sumber data dalam hal ini adalah tinjauan kritis kajian terhadap implementasi pendidikan karakter di Madrasah.

2. Waktu Penelitian

Penelitian ini dilaksanakan pada bulan November sampai dengan Desember tahun 2021.

3. Teknik Pengumpulan Data

Pengumpulan data yang dilakukan dengan menggunakan teknik dokumentasi yaitu mengadakan survey bahan kepustakaan untuk mengumpulkan bahan-bahan dan studi literatur yakni mempelajari bahan-bahan yang berkaitan dengan objek penelitian. Teknik pengumpulan data menurut (Bahri, 2021) mengemukakan bahwa merupakan langkah yang paling strategis dalam penelitian karena tujuan untama dari penelitian adalah mendapatkan data. Terdapat beberapa cara atau teknik dalam mengumpulkan data, diantaranya adalah observasi dan dokumentasi. Sumber data yang digunakan dalam penelitian ini mencakup data primer dan sekunder, Menurut (Hanafiah, 2021) bahwa data primer adalah data yang dikumpulkan langsung dari individu-individu yang diselidiki atau data tangan pertama, sedangkan data sekunder adalah data yang ada dalam pustaka-pustaka. Data primer dalam penelitian ini adalah buku-buku terkait tinjauan kritis kajian terhadap implementasi pendidikan karakter di Madrasah, dan data sekunder didapatkan dari jurnal-jurnal baik nasional maupun internasional.

4. Alat Pengumpulan Data

Dalam penelitian ini, penulis akan menggunakan metode dokumentasi sebagai alat untuk pengumpul data karena penelitian ini adalah penelitian kepustakaan, dengan kata lain, menurut (Juhji, 2020) bahwa teknik ini digunakan untuk menghimpun data-data dari sumber primer maupun sekunder.
5. Teknik Analisis Data

Analisis data tidak saja dilakukan setelah data terkumpul, tetapi sejak tahap pengumpulan data proses analisis telah dilakukan. Penulis menggunakan strategi analisis "kualitatif", strategi ini dimaksudkan bahwa analisis bertolak dari data-data dan bermuara pada kesimpulan-kesimpulan umum. Berdasarkan pada strategi analisis data ini, dalam rangka membentuk kesimpulan-kesimpulan umum analisis dapat dilakukan menggunakan kerangka pikir "induktif". Menurut (Sugiyono, 2015) bahwa metode pembahasan menggunakan metode deskriptif-analisis, yaitu menjelaskan serta mengelaborasi ide-ide utama yang berkenaan dengan topik yang dibahas, kemudian menyajikannya secara kritis melalui sumber-sumber pustaka primer maupun skunder yang berkaitan dengan tema.

6. Prosedur Penelitian

Data pada penelitian ini dicatat, dipilih dan kemudian diklasifikasikan sesuai dengan kategori yang ada, pendekatan yang digunakan adalah pendekatan deskriptif analitis. Menurut (Nasser, 2021) bahwa deskriptif analitis (descriptive of analyze research), yaitu pencarian berupa fakta, hasil dari ide pemikiran seseorang melalui cara mencari, menganalisis, membuat interpretasi serta melakukan generalisasi terhadap hasil penelitian yang dilakukan. Prosedur penelitian ini menurut (Na'im, 2021) adalah untuk menghasilkan data deskriptif yang berupa data tertulis setelah melakukan analisis pemikiran (content analyze) dari suatu teks. Setelah penulis mengumpulkan bahan-bahan yang berhubungan dengan masalah yang akan dibahas dalam penelitian ini kemudian penulis menganalisis dan menarasikan untuk diambil kesimpulan.

\section{HASIL DAN PEMBAHASAN}

Dalam pembahasan ini akan dibahas tentang Hakekat Pendidikan Karakter, Fungsi dan Tujuan Pendidikan Karakter, Prinsip Pengembangan Pendidikan Karakter, serta Indikator Keberhasilan Madrasah dan Kelas dalam Pendidikan Karakter.

1. Hakekat Pendidikan Karakter

Dalam penguatan pendidikan karakter bahwa lembaga pendidikan hingga kini masih diandalkan sebagai media yang sangat ampuh membangun kecerdasan sekaligus karakter anak menjadi lebih baik, oleh karena itu pendidikan secara terus menerus dibangun 
dan dikembangkan agar dari proses pelaksanaannya menghasilkan generasi yang diharapkan (Darmawan, 2021). Pendidikan merupakan kebutuhan yang mutlak bagi kehidupan manusia yang harus dipenuhi sepanjang hayat, sebab tanpa pendidikan mustahil manusia dapat berkembang dengan baik, disinilah kemudian besarnya peran pendidikan karakter dalam proses pendidikan yaitu untuk membentuk butiran kebaikan supaya bisa tertanam dalam diri setiap generasi. Menurut (Arifudin, 2021) bahwa pembentukan karakter dalam diri tersebut harus ditanamkan sejak masih usia anak yaitu masa dimana pembentukan kepribadian sangat diperlukan, karena jika nilai-nilai luhur sudah terbentuk dalam diri anak sejak dini maka ketika dewasa ia akan menjadi manusia yang bertanggungjawab dan bermartabat.

Tujuan pendidikan nasional itu merupakan rumusan mengenai kualitas manusia Indonesia yang harus dikembangkan oleh setiap satuan pendidikan, oleh karena itu rumusan tujuan pendidikan nasional menjadi dasar dalam pengembangan pendidikan budaya dan karakter bangsa. Berdasarkan Peraturan Presiden nomor 87 tahun 2017 tentang Penguatan Pendidikan (PPK) pasal 1 yang di maksud PPK adalah: Penguatan Pendidikan Karakter yang selanjutnya disingkat PPK adalah gerakan pendidikan di bawah tanggung jawab satuan pendidikan untuk memperkuat karakter peserta didik melalui harmonisasi olah hati, olah rasa, olah pikir, dan olahraga dengan pelibatan dan kerja sama antara satuan pendidikan, keluarga dan masyarakat sebagai bagian dari Gerakan Nasional Revolusi Mental (GNRM). (Pepres nomor 87 Tahun 2017). Secara terminologi (istilah) karakter diartikan sebagai sifat manusia pada umumnya yang bergantung pada faktor kehidupannya, karakter adalah sifat kejiwaaan, akhlak, atau budi pekerti yang menjadi ciri khas seseorang atau sekelompok orang, karakter merupakan nilai-nilai perilaku manusia yang berhubungan dengan Tuhan Yang Maha Esa, diri sendiri, sesama manusia, lingkungan dan kebangsaan yang terwujud dalam pikiran, sikap, perasaan, perkataan dan perbuatan berdasarkan norma-norma agama, hukum dan tata karma, budaya dan adat istiadat. Karakter dapat juga diartikan sama dengan akhlak dan budi pekerti sehingga karakter bangsa sama dengan akhlak bangsa atau budi pekerti sehingga karakter bangsa sama dengan akhlak bangsa atau budi pekerti bangsa (Darmayani, 2021).

\section{Fungsi dan Tujuan Pendidikan Karakter}

Penyelenggaraan pendidikan karakter di sekolah penting dilakukan meskipun sekolah atau institusi pendidikan bukan satu-satunya lembaga yang bertanggung jawab dan berperan dalam membentuk karakter peserta didik, disamping madrasah proses pendidikan karakter juga menjadi tanggung-jawab keluarga dan masyarakat, dalam keluarga orang tua memiliki peran penting dalam proses pendidikan karakter ini (Hasbi, 2021). Sebelum para peserta didik memasuki dunia sekolah, keluarga merupakan tempat pertama di mana anak memperoleh dan mengalami pendidikan karakter, keberhasilan pendidikan karakter sangat tergantung pada sinergi antara sekolah, keluarga dan masyarakat, berdasarkan Panduan Pelaksanaan Pendidikan Karakter Kementerian Pendidikan Nasional (2011) dijelaskan bahwa Pendidikan karakter berfungsi membangun kehidupan kebangsaan yang multikultural, membangun peradaban bangsa yang cerdas, berbudaya luhur, dan mampu berkontribusi terhadap pengembangan kehidupan ummat manusia; mengembangkan potensi dasar agar berhati baik, berpikiran baik, dan berperilaku baik serta keteladanan baik, serta membangun sikap warganegara yang cinta damai, kreatif, mandiri.

\section{Prinsip Pengembangan Pendidikan Karakter}

Pada prinsipnya pengembangan karakter tidak dimasukkan sebagai pokok bahasan tetapi terintegrasi ke dalam mata pelajaran, pengembangan diri dan budaya Madrasah (Tanjung, 2022). Oleh karena itu guru dan Madrasah perlu mengintegrasikan nilai-nilai yang dikembangkan dalam pendidikan karakter dalam Kurikulum, Silabus dan Rencana Program Pembelajaran (RPP) yang sudah ada. Prinsip pembelajaran yang digunakan dalam pengembangan pendidikan budaya dan karakter bangsa mengusahakan agar peserta didik mengenal dan menerima nilai-nilai budaya dan karakter bangsa sebagai milik mereka dan bertanggung jawab atas keputusan yang diambilnya melalui tahapan mengenal pilihan, menilai pilihan, menentukan pendirian dan selanjutnya menjadikan suatu nilai sesuai dengan keyakinan diri, dengan prinsip ini peserta didik belajar melalui proses berpikir, bersikap dan berbuat. Ketiga proses ini 
dimaksudkan untuk mengembangkan kemampuan peserta didik dalam melakukan kegiatan sosial dan mendorong peserta didik untuk melihat diri sendiri sebagai makhluk sosial.

4. Indikator Keberhasilan Madrasah dan Kelas dalam Pendidikan Karakter

Karakter dikembangkan melalui tahap pengetahuan (knowing), pelaksanaan (acting), dan kebiasaan (habit), oleh karena itu karakter tidak bisa diajarkan sebatas pengetahuan. Seseorang yang memiliki pengetahuan tentang kebaikan belum tentu mampu bertindak sesuai dengan pengetahuan yang dimilikinya itu, terutama ketika ia tidak terlatih untuk melakukan kebaikan tersebut (Febrianty, 2020), dengan demikian untuk menjadi orang yang berkarakter diperlukan tiga komponen karakter yang baik (component of good character), yaitu moral knowing atau pengetahuan tentang moral, moral feeling atau perasaan tentang moral, dan moral action atau perbuatan moral. Ketiga komponen ini perlu diberikan kepada peserta didik agar ia mampu memahami, merasakan, dan melakukan nilai-nilai kebajikan yang ia ketahui.

Menurut (Fitri, 2012) ada dua jenis indikator yang ingin dikembangkan terkait pendidikan Nilai-Nilai Karakter dan Budaya Bangsa yaitu Indikator untuk Madrasah dan kelas, indikator Madrasah dan kelas adalah penanda yang digunakan oleh Kepala Madrasah, guru dan personalia. Madrasah dalam merencanakan, melaksanakan dan mengevaluasi, madrasah sebagai lembaga pelaksana pendidikan nilai karakter dan budaya bangsa. Indikator ini berkenaan juga dengan kegiatan Madrasah yang diprogramkan dan kegiatan Madrasah sehari-hari (rutin), indikator dirumuskan dalam bentuk perilaku peserta didik di kelas dan Madrasah yang dapat diamati melalui pengamatan guru ketika seorang peserta didik melakukan suatu tindakan di Madrasah, tanya jawab dengan peserta didik, jawaban yang diberikan peserta didik terhadap tugas dan pertanyaan guru, serta tulisan peserta didik dalam laporan dan pekerjaan rumah, indikator berfungsi bagi guru sebagai kriteria untuk memberikan pertimbangan tentang perilaku untuk nilai tertentu telah menjadi perilaku yang dimiliki peserta didik.

\section{SIMPULAN DAN SARAN}

\section{A. Simpulan}

Berdasarkan pemaparan pada penelitian implementasi pendidikan karakter di Madrasah ini dapat disimpulkan bahwa dalam Islam, pendidikan tidak hanya proses mentransfer ilmu dari guru kepada murid. Pendidikan dalam Islam juga diiringi dengan upaya keteladanan (qudwah) dari pendidik dalam pembentukan karakter peserta didik. Oleh karena itu upaya melahirkan seorang yang berilmu, berkarakter, beradab dan berakhlak mulia adalah bagian dari pendidikan. Madrasah sebagai lembaga pendidikan harus melaksanakan pengembangan karakter terintegrasi ke dalam mata pelajaran, pengembangan diri dan budaya Madrasah. Sehingga guru dan Madrasah perlu mengintegrasikan nilai-nilai yang dikembangkan dalam pendidikan karakter dalam Kurikulum, Silabus dan Rencana Program Pembelajaran (RPP) yang sudah ada. Prinsip pembelajaran yang digunakan dalam pengembangan pendidikan budaya dan karakter bangsa mengusahakan agar peserta didik mengenal dan menerima nilainilai budaya dan karakter bangsa sebagai milik mereka dan bertanggung jawab atas keputusan yang diambilnya melalui tahapan mengenal pilihan, menilai pilihan, menentukan pendirian, dan selanjutnya menjadikan suatu nilai sesuai dengan keyakinan diri.

\section{B. Saran}

Pembahasan terkait penelitian kajian terhadap implementasi pendidikan karakter di Madrasah dalam penelitian ini masih sangat terbatas dan membutuhkan banyak masukan. Saran untuk penulis selanjutnya adalah mengkaji lebih dalam dan secara komprehensif terkait kajian terhadap implementasi pendidikan karakter di Madrasah. Adapun saran yang dapat diberikan sebagai berikut:

1. Para tenaga pendidik harus mampu mengimplementasian pendidikan karakter dengan baik terhadap para peserta didik dengan cara menyiapkan perangkat pembelajaran, metode pembelajaran yang gampang dicerna oleh para peserta didik.

2. Dalam muatan kurikulum harus menguatkan pembelajaran pendidikan karakter. Hal ini dikarenakan pendidikan karakter di sekolah sangat dibutuhkan mengingat perkembangan zaman dan kemajuan ilmu pengetahuan dan teknologi harus di 
barengi dengan implementasi pendidikan karakter dengan baik di sekolah.

\section{DAFTAR RUJUKAN}

Anshori. (2012). Kenakalan Remaja, Studi kasus Pondok Pinang Pinggiran Kota Metropolitan Jakarta. Jakarta: Hasil Penelitian.

Arifudin, 0. (2018). Pengaruh Pelatihan Dan Motivasi Terhadap Produktivitas Kerja Tenaga Kependidikan STIT Rakeyan Santang Karawang. MEA (Manajemen, Ekonomi, \& Akuntansi), 2(3), 209-218.

Arifudin, 0. (2019). Manajemen Sistem Penjaminan Mutu Internal (SPMI) Sebagai Upaya Meningkatkan Mutu Perguruan Tinggi. MEA (Manajemen, Ekonomi, \& Akuntansi), 3(1), 161-169.

Arifudin, O. (2020). Psikologi Pendidikan (Tinjauan Teori Dan Praktis). Bandung: Widina Bhakti Persada.

Arifudin, O. (2021). Konsep Dasar Pendidikan Anak Usia Dini. Bandung: Widina Bhakti Persada Bandung.

Bahri, A. S. (2021). Pengantar Penelitian Pendidikan (Sebuah Tinjauan Teori dan Praktis). Bandung: Widina Bhakti Persada.

Darmawan, I. P. A. (2021). Total Quality Management Dalam Dunia Pendidikan" Model, Teknik Dan Impementasi". Bandung: Widina Bhakti Persada Bandung.

Darmayani, S. (2021). Pembelajaran Digital. Bandung : Widina Bhakti Persada.

Febrianty, F. (2020). Kepemimpinan \& Prilaku Organisasi Konsep Dan Perkembangan. Bandung: Widina Bhakti Persada.

Fitri. (2012). Pendidikan Karakter Berbasis Nilai dan Etika di Madrasah. Jogyakarta : AR-Ruzz Media.

Gunawan. (2012). Pendidikan Karakter (Konsep dan Implementasi). Bandung: Alfabeta.

Hanafiah, H. (2021). Pelatihan Software Mendeley Dalam Peningkatan Kualitas
Artikel Ilmiah Bagi Mahasiswa. Jurnal Karya Abdi Masyarakat, 5(2), 213-220.

Hariyanto. (2013). Konsep dan Model Pendidikan Karakter. Bandung:Remaja Rosdakarya.

Hasbi, I. (2021). Administrasi Pendidikan (Tinjauan Teori Dan Praktik). Bandung: Widina Bhakti Persada.

Irwansyah, R. (2021). Perkembangan Peserta Didik. Bandung : Widina Bhakti Persada.

Juhji. (2020). Manajemen Humas Sekolah. Bandung: Widina Bhakti Persada.

Kemendiknas. (2010). Pengembangan Pendidikan Budaya dan Karakter Bangsa. Jakarta: Kementerian Pendidikan Nasional.

Ma'ruf, F. (2021). Pengembangan Game Edukasi Berbasis Flash Sebagai Sarana Belajar Siswa PAUD. Ainara Journal (Jurnal Penelitian Dan PKM Bidang Ilmu Pendidikan), 2(3), 143147. https://doi.org/10.54371/ainj.v2i3.68

Majid. (2012). Pendidikan Karakter Perspektif Islam. Bandung: Remaja Rosdakarya.

Muslich. (2011). Nilai Karakter Refleksi Untuk Pendidikan Karakter. Jogyakarta: Laksbang Pressindo.

Na'im, Z. (2021). Manajemen Pendidikan Islam. Bandung : Widina Bhakti Persada.

Nasser, A. A. (2021). Sistem Penerimaan Siswa Baru Berbasis Web Dalam Meningkatkan Mutu Siswa Di Era Pandemi. Biormatika: Jurnal Ilmiah Fakultas Keguruan Dan Ilmu Pendidikan, 7(1), 100-109.

Peraturan Presiden Republik Indonesia Nomor 87 Tahun 2017 Tentang Penguatan Pendidikan Karakter (PPK).

Qadri. (2003). Pendidikan (Agama) untuk Membangun Etika Sosial. Semarang: Aneka Ilmu.

Rahayu, Y. N. (2020). Program Linier (Teori Dan Aplikasi). Bandung : Widina Bhakti Persada. 
Sofyan, Y. (2020). Peranan Konseling Dosen Wali Dalam Meningkatkan Motivasi Belajar Mahasiswa Di Perguruan Tinggi Swasta Wilayah LLDIKTI IV. Jurnal Bimbingan Dan Konseling Islam, 10(2), 237-242.

Sugiyono. (2015). Metode Penelitian Pendidikan (Pendekatan Kuantitatif,. Kualitatif dan $R \& D)$. Bandung : CV. Alfabeta.

Supriani, Y. (2022). Peran Manajemen Kepemimpinan dalam Pengelolaan Lembaga Pendidikan Islam. JIIP-Jurnal Ilmiah Ilmu Pendidikan, 5(1), 332-338.

Syafri. (2012). Pendidikan Karakter berbasis alQur'an. Jakarta: Rajawali Pers.
Tanjung, R. (2020). Pengaruh Penilaian Diri Dan Efikasi Diri Terhadap Kepuasan Kerja Serta Implikasinya Terhadap Kinerja Guru. Jurnal Ilmiah MEA (Manajemen, Ekonomi, Dan Akuntansi), 4(1), 380-391.

Tanjung, R. (2022). Manajemen Penyelenggaraan Pendidikan Inklusi pada Lembaga Pendidikan Islam. JIIP-Jurnal Ilmiah Ilmu Pendidikan, 5(1), 339-348.

Ulfah, U. (2022). Kepemimpinan Pendidikan di Era Disrupsi. JIIP-Jurnal Ilmiah Ilmu Pendidikan, 5(1), 153-161.

Wiyani. (2012). Manajemen Pendidikan Karakter Konsep dan Implementasinya di Madrasah. Jogyakarta : Pedagogia. 